\title{
Assessing Groundwater Vulnerability in Azraq Basin Area by a Modified DRASTIC Index
}

\author{
Alsharifa Hind Jasem, Marwan Alraggad \\ Water and Environment Research and Study Center (WERSC), University of Jordan, Amman, Jordan \\ E-mail: \{s.jasem,m.raggad\}@ju.edu.jo \\ Received October 7, 2010; revised October 18, 2010; accepted October 21, 2010
}

\begin{abstract}
Groundwater is the main source for water supply in Jordan. Surface water is limited due to low precipitation rates. Studying groundwater vulnerability helps to protect this main source of depletion and degradation for present and coming generations. Different vulnerability indices were built taking into consideration the different environmental setting of the different areas for which these indices were established. Environmental and weather conditions are very important factors in determination groundwater vulnerability hence arid to semi arid areas conditions must be taken into account in applying different indices. The reason after selecting Azraq as a rest point is related directly to the availability of fresh water resources in the form of the wetland supported by many potential springs making Azraq a rich environment for economic activities. A modified DRASTIC vulnerability index was applied to Azraq basin area due to its special climate and wetland area conditions. The index takes the special landuse and the different groundwater depths into consideration and suggests a few measures to alleviate the vulnerability of the groundwater resources due to overexploitation and human activities changing the value of landuse. Azraq basin represents four different vulnerability classes, ranging from Low to very high vulnerability class. The lower vulnerability class areas are distributed in theareas with high depth to water table and low recharge areas with low human activities. The higher vulnerability classes are shown in the areas with high possibility of the pollutants to reach the groundwater. The modified DRASTIC index added the value of the human activity and the structural features in the area which give a more ease to pollutant to permit the aquifer.
\end{abstract}

Keywords: Groundwater, Vulnerability, Azraq, DRASTIC Index, Aquifer, GIS

\section{Introduction}

Jordan as many other countries in the world face serious problems related to water shortages, that negatively affects its entire development. Worldwide Jordan is considered as one of the four poorest countries in water resources. The population growth rate is about $2.9 \%$ (1998-2002), and is the 9th highest in the world [1].

Jordan suffers from a strong water shortage due to high population growth, industrialization, general development of the country, increasing water demand on the existing resources in addition to declining rainfall and rising temperature as a result of climatic changes.

The term 'vulnerability of groundwater to contamination' was introduced by Margat in 1968. But, the term 'vulnerability' is not restricted to groundwater it is used in a wide sense to describe the sensitivity of any kind of stress. The concept of groundwater vulnerability is based on the assumption that the physical environment provides some natural protection to groundwater against human impacts, especially with regard to contaminants entering the subsurface environment [2].

DRASTIC is an overlay and indexing method which is widely used to assess groundwater vulnerability to a wide range of potential contaminants. Merchant [3] argued that DRASTIC has been used throughout the world with exceptional frequency.

In this model, spatial datasets on Depth to groundwater Recharge by rainfall, Aquifer type, Soil properties, Topography, Impact of the vadose zone and the hydraulic Conductivity of the aquifer are combined [4].

The main concept is the evaluation and delineation of vulnerability, which has actually no material content. But its application will be acquired when the intrinsic vul- 
nerability of a certain area will be associated with a source of danger. In this case integrated vulnerability is meant, which is defined by the interaction of intrinsic vulnerability of a hydrogeological system and the sources of danger [5].

Groundwater vulnerability studies are expected to draw the attention of the landuse planners and decision makers to the effects of human activities at the ground surface to the groundwater, especially the result of harmful contaminants into aquifer [6].

Different environmental parameters interfere when anticipating the amount and location of impurities that may affect the aquifers. Groundwater settings, hydrological and hydrogeological conditions, landuse parameters, environmental issues, soil parameters and other elements which may vary from one aquifer to other and from one area to another are used to determine the vulnerability of groundwater [2].

Groundwater vulnerability assessments are used to analyze the effects of un-established projects on the groundwater resources. Landuse should therefore be based on the determination of the statuesque of water quality and the impact of future projects on it.

Parameters such as soil type, recharge amounts, depth to the groundwater, slope of the topography, impact of vadose zone, aquifer media properties [3], and presence of geologic features in the area were used in the course of the present study to delineate the groundwater vulnerability zones in Azraq area.

\subsection{Study Area}

The Azraq Basin is one of the important ground water basins in Jordan. It forms a large resource of good-quality ground and surface water in Jordan. The Basin is located in the northeastern part of the country, extending northwards into Syria and southwards touching the border with Saudi Arabia, (Figure 1). Azraq Basin consists of three aquifer systems, the upper shallow fresh water basalt aquifer currently under the threat of salinization due to overexploitation; the middle limestone brackish water aquifer (600 to $15,000 \mathrm{mg} / \mathrm{l}$ ) and the deep sandstone aquifer which has low yields and poor quality water, [7].

The Azraq oasis is a unique ecosystem in a fragile environment containing a wealth of biodiversity and habitats, and is considered as the richest habitat of all existing wetlands, which are extremely rare in the region. The Azraq Oasis was especially important for migratory birds, with up to a million birds utilizing the area during the course of a single spring migration, the presence of such wet land in this extended tuff desert gave the chance for migratory birds to find peace and food to get the power to go on in their long trip [7].

Historically Azraq represents the treble junction between the three major civilizations in the Middle East (Aljazeera, Iraq and Alsham) which is shown in the desert castles distributed all around the area and along the trade way as shown in the map below.

Azraq castle is one of the most important desert castles according to the presence of fresh water with all the natural characteristics related to water like flora and fauna diversity.

Also, Azraq area contains many agricultural activities and urban centers that depend on septic tanks are the most hazardous potentials that may affect the groundwater. Groundwater vulnerability maps are thought of to draw the attention to plan new projects or to put the red alarm for high risk areas in order to manage the water system there.

\section{Methodology}

Considering the special conditions in semi arid areas such as aridity, strong fluctuations in precipitation amounts and distribution, soil properties and thin soil thicknesses, barren rocks, landuse, etc, a new vulnerability index is suggested, based mainly on the differentiation of the depth to groundwater and the ease of the pollutants to migrate to and within the groundwater, geological structures distributions, soil type, thickness and landuse, thhe rating of theses variable are depends on the importance of them in the water pollution.

This DRASTIC index given in the equation above is considered as an indicator for pollution potential [3]. The governing equation of the DRASTIC index was defined by Knox et al., [5]; Fortin et al., [8]; and Fritch et al.,

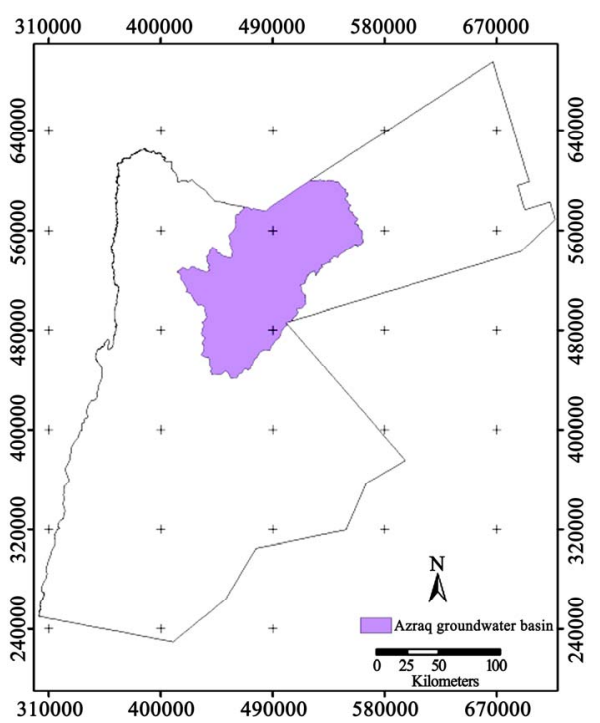

Figure 1. Azraq basin location map. 
[9], Table 1 shows the appriviations for the index:

$$
\begin{aligned}
\mathrm{DI}= & \mathrm{DrDw}+\mathrm{RrRw}+\mathrm{ArAw}+\mathrm{SrSw} \\
& +\mathrm{TrTw}+\mathrm{IrIw}+\mathrm{CrCw}
\end{aligned}
$$

The modified DRASTIC index is supposed to be suitable for different aquifer rock types especially for arid and semi arid areas with thin soil covers and heavily jointed and fractured fracture rocks [10].

The main factors in this index are:

1) Depth to water table: This is important to describe the distance that the pollutants have to pass to reach the groundwater; Table 2 shows the values of $\mathrm{D}$ factor.

2) Recharge to the groundwater as a portion from rainfall amounts. Depends on rainfall data, soil permeability and topographic setting, Tables $\mathbf{3}$ and $\mathbf{4}$ show the building of $\mathrm{R}$ factor.

3) Landuse: landuse is an important factor that must be included in groundwater vulnerability maps because it strongly affects the groundwater qualityas shown in Table 5.

4) Structural setting: Fissures, faults and joints form very important factors in vulnerability prediction [10],

Table 1. Vulnerability index factors and their weights, $[10,11]$.

\begin{tabular}{cc}
\hline Factor & Weight \\
\hline Depth to water table & 9 \\
Recharge amount & 8 \\
Landuse & 7 \\
Lineaments & 7 \\
Aquifer media & 5 \\
Vadose zone & 5 \\
Soil types & 4 \\
Slope factor & 1 \\
\hline
\end{tabular}

Table 2. Rates of depth to groundwater table, [11].

\begin{tabular}{cc}
\hline Depth to water $(\mathrm{m})$ & Rate \\
\hline $0-2$ & 10 \\
$2-10$ & 8 \\
$10-20$ & 6 \\
$20-40$ & 4 \\
$40-60$ & 2 \\
$>60$ & 1 \\
\hline
\end{tabular}

Table 3. Building of recharge factor, [14].

\begin{tabular}{ccc}
\hline Factor & Class & Value \\
\hline Rainfall & $<500 \mathrm{~mm}$ & 1 \\
& $500-800 \mathrm{~mm}$ & 2 \\
\multirow{2}{*}{ Slope } & $>800 \mathrm{~mm}$ & 3 \\
& $<2 \%$ & 3 \\
& $2-10 \%$ & 2 \\
Soil permeability & $>10 \%$ & 1 \\
& Low & 1 \\
& Medium & 2 \\
& High & 3 \\
\hline
\end{tabular}

Table 6 shows the values of this factor.

5) Topographic slope: This describes the ability of pollutants to infiltrate into the vadose zone and reach the aquifer, the gentle slope areas reflects the higher in vulnerability ones owing to the ease of water to stay on the surface for as long as possible to infiltrate to the groundwater [11], as shown in Table 10.

6) Aquifer media: This hydrogeological factor describes the ability of pollutants to move within the aquifer according to the type of that aquifer, Table 8, [11].

7) Soil media: This factor describes the ability of pollutants to move within the soil down to the groundwater according to the size distribution of soil cover, Table $\mathbf{9}$, [11].

8) Vadose zone properties: This hydrogeological factor describes the types of rocks overlaying the aquifer itself, the rocks that permit the recharged water into the aquifer. The more permeable the rocks are the higher the vulnerability rate, Table 7, [11].

\section{Results}

Depth to the groundwater was determined using the most recent well records data determined from the Ministry of Water and Irrigation MWI, 2010 [12]. These data were converted to raster maps in the environment of geo

Table 4. Model builder of the corresponding standardized scale [14].

\begin{tabular}{|c|c|}
\hline Model builder & Standardized scale \\
\hline 3 & 1 \\
\hline 4 & 2 \\
\hline 5 & 3 \\
\hline 6 & 4 \\
\hline 7 & 5 \\
\hline 8 & 6 \\
\hline 9 & 7 \\
\hline
\end{tabular}

Table 5. Rate of landuse factor, [10].

\begin{tabular}{lc}
\hline \multicolumn{1}{c}{ landuse } & Rate \\
\hline Rain fed agriculture & 1 \\
Irrigated agriculture & 3 \\
Urban areas & 5 \\
Barred rocks & 1 \\
WWTP & 4 \\
Streams (related to wwtp) & 6 \\
Streams (not related to wwtp) & 3 \\
dams & 5 \\
\hline
\end{tabular}

Table 6. Rate of lineaments factor, [10].

\begin{tabular}{cc}
\hline Structures distribution & Rate \\
\hline Fissures, Joints and Faults and dry wadis & 2 \\
\hline
\end{tabular}


Table 7. Rate of vadose zone factor, [10].

\begin{tabular}{cc}
\hline Vadose zone & Rate \\
\hline Not covered & 4 \\
Soil & 3 \\
Unconfined unit & 2 \\
Confining unit & 1 \\
\hline
\end{tabular}

Table 8. Rate of aquifer media factors, [11].

\begin{tabular}{cc}
\hline Aquifer media & Rate \\
\hline Limestone & 1 \\
Bedded sandstone & 2 \\
Sands and gravels & 3 \\
Basalt & 5 \\
Limestone with chalk & 4 \\
\hline
\end{tabular}

Table 9. Soil media distribution, [11].

\begin{tabular}{cc}
\hline Soil media & Rate \\
\hline Clay & 1 \\
Silty clay loam & 2 \\
Loam & 3 \\
Sand & 4 \\
\hline
\end{tabular}

Table 10. Slope factor distribution, [14].

\begin{tabular}{cc}
\hline Slope factor & Rate \\
\hline$>2 \%$ & 7 \\
$2-6 \%$ & 6 \\
$6-10 \%$ & 5 \\
$10-16 \%$ & 3 \\
$16-25 \%$ & 2 \\
$>25 \%$ & 1 \\
\hline
\end{tabular}

graphic information system Arc GIS 9.1 by ESRI [13], and then classified into classes suitable to the vulnerability index data.

Depth to groundwater table factor was ranged from $20 \mathrm{~m}$ in the ventral areas up to $710 \mathrm{~m}$ in Jebal al Drouz area according to the occurrence of the groundwater, these depths are reflected in the D factor vulnerability rates ranging from 1-4 according Table 2, the depth to water map is shown in Figure 2.

Recharge to the groundwater (R-factor) is the second important factor included in this index. This recharge is calculated as a portion of rainfall [14], precipitation is the primary source of groundwater because precipitation infiltrates through the ground surface and percolates down to the water table. Areas with higher rainfall amounts pose higher potential and more vulnerable effects on the aquifer. Many parameters affect the R factor; Such as rainfall distribution, slope and topographic relief and soil permeability. In order to create the rechargefactor layer, an overlay process is conducted to combine layers representing: rainfall in mm per year, topography of the area to produce the slope map with a certain slope $\%$ intervals and permeability of soils [13]. Building this factor process is given in Tables $\mathbf{2} \& \mathbf{3}$.

For the study area this factor ranged from 1-6, the higher numbers reflect the higher recharged area or the higher the rainfall amount, gentle topographic slope and high soil permeability. The distribution of this factor over the basin area is shown in Figure 3. The landuse factor describes the existing activities in the area which may affect the groundwater quality. This factor is determined by using the landuse maps of MWI, 2003 [15]. The thematic layer produced for this factor is given in Figure 4.

The geologic structural settings of the study area combined with the soil covers enhance the water percolation

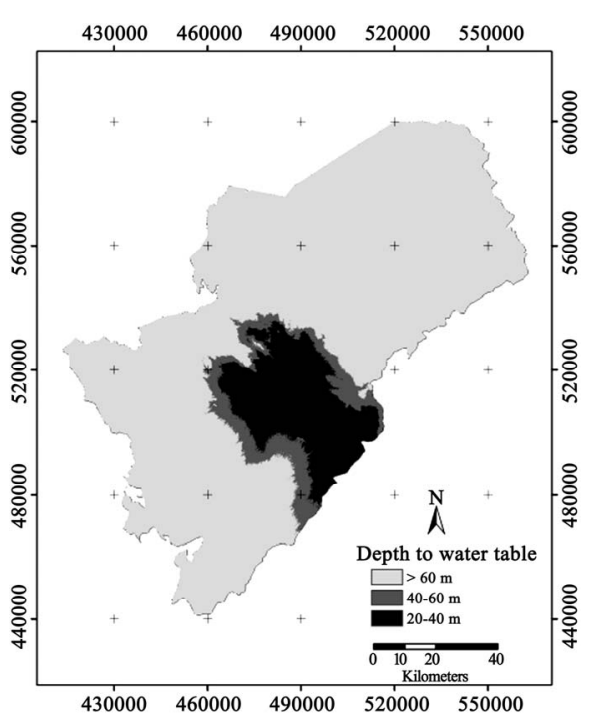

Figure 2. Depth to water table map in the study area.

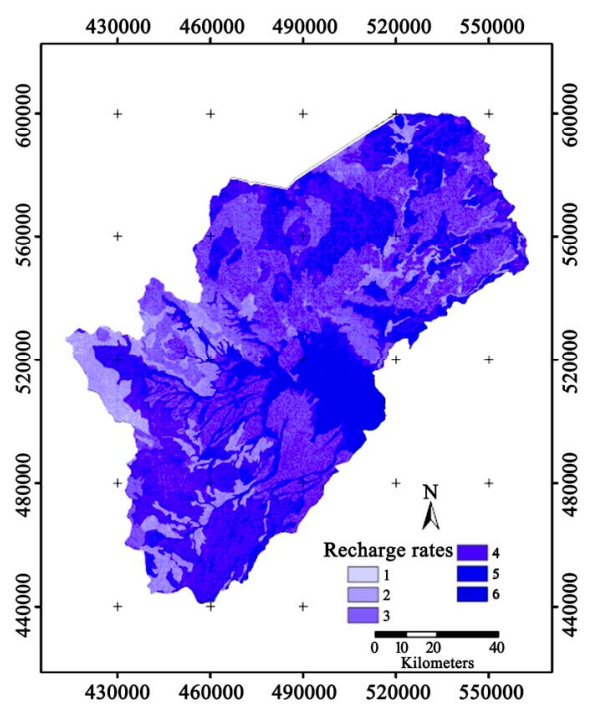

Figure 3. Recharge to the groundwater rates in the study area. 
down to the groundwater. Geologic maps from natural resources authority [16], were used to determine the weight for the area according to this factor. The thematic layer produced for this factor is given in Figure 5.

The topographic slope represents the geomorphologic features of the basin surface. This factor was included in general in the recharge factor calculations. In this step, the Digital elevation model (DEM) [12], was used to create the slope map for the area. This slope will be produced in more detailed intervals. A low weight was given to the factor because it was included before. The values of the topographic slope factor ranged from 1-7 as shown in Figure 6. Most of the basin area has gentles lopes area with the rate 7 and hence it is the higher vul-



Figure 4. Landuse distribution map in Azraq basin.

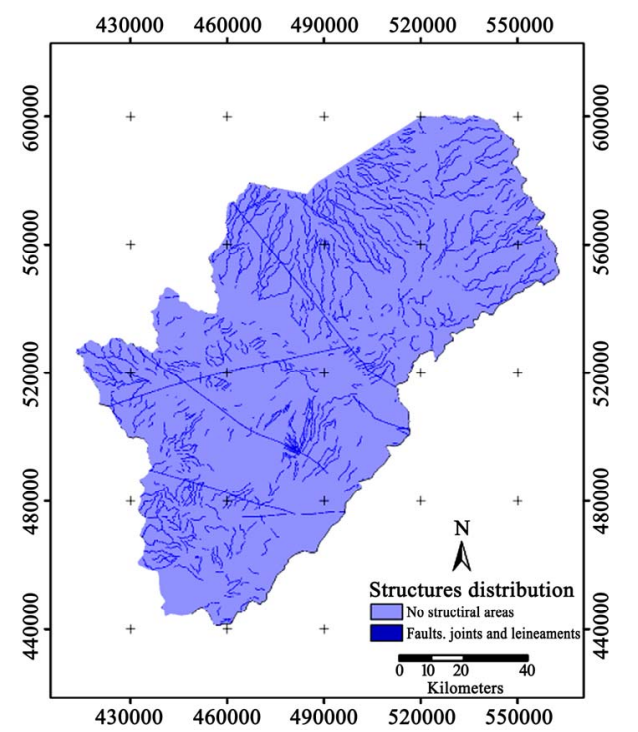

Figure 5. Structural features distribution in the study area. nerability rate.

The aquifer media is the factor that affects this index and it describes the properties of the geologic beds that contain the water. Hydrogeologic maps [17], are used to determine this factor. The thematic layer produced for this factor is given in Figure 7.

Soil data were taken from Ministry of Agriculture maps $[18,19]$. These maps illustrate the distribution of soil particles size and texture of soil media. The study area contains mainly loamy, sandy and some clayey texture soils. The rate of those texture types ranged from 1-4 as shown in Figure 8.

The vadose zone factor describes the types of rocks that overlie the aquifer. The properties of this zone

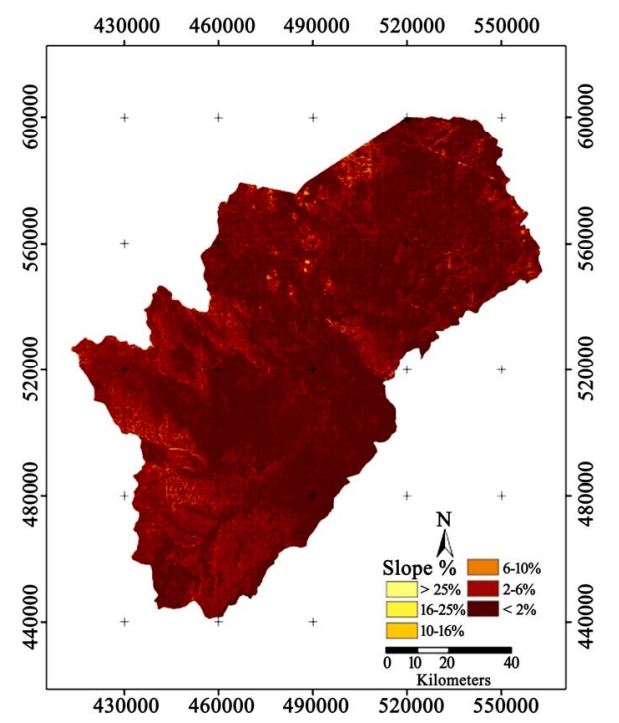

Figure 6. Slope map distribution in the study area.

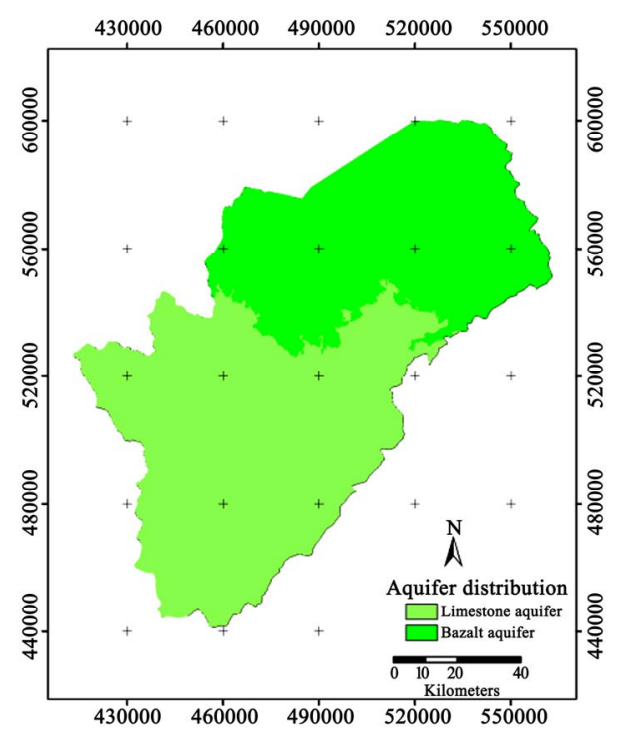

Figure 7. Aquifer distribution map in the study area. 
provide protection to the groundwater. In parts of the study area the aquifer crops out to the surface and no vadose zone exists. Therefore, a high vulnerability rate is given according to the classification of this factor.

In the study area, the presence of thick gravel beds in some wadis enhances the groundwater infiltration as a result of their high permeability. It also prevents or impedes evaporation from the soil. Such areas enhance the vulnerability values. The distribution of gravel beds in the study area is shown in Figure 9.

Applying the final vulnerability map needs to multiply each vulnerability factor by its vulnerability weight (Table 1), according to the importance of each factor in the groundwater contamination potentials. Therefore, these maps will represent the vulnerability index rating, building of the final vulnerability map shown in Table 11.

The final vulnerability map for the Azraq basin has the values of 62 to 203. These values give vulnerability classes of low, moderate, high and very high vulnerabilities classes as shown in Figure 10.

\subsection{Validation of Results}

Usually vulnerability maps describes expectation to the potentiality of an aquifer to be polluted, in order to be on the safe side concerning the results of vulnerability mapping every worked out index must be validated to show the degree of accuracy of this index.

Since groundwater is exposed to all types of pollution, whether those resulting from human or natural sources, the groundwater, if vulnerable to any of these pollution sources must contain residues of the septic pollutants. Groundwater bodies exposed to demotic types of pollution

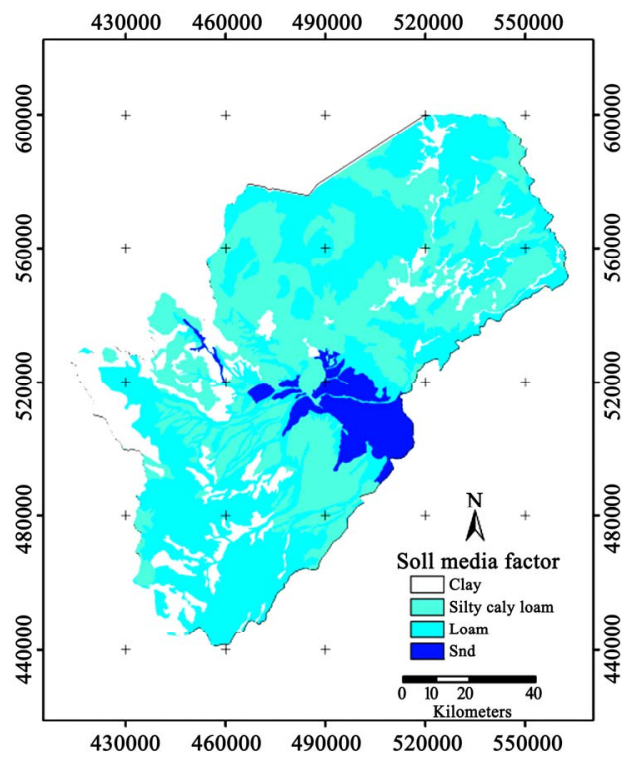

Figure 8. soil map in Azraq basin area.

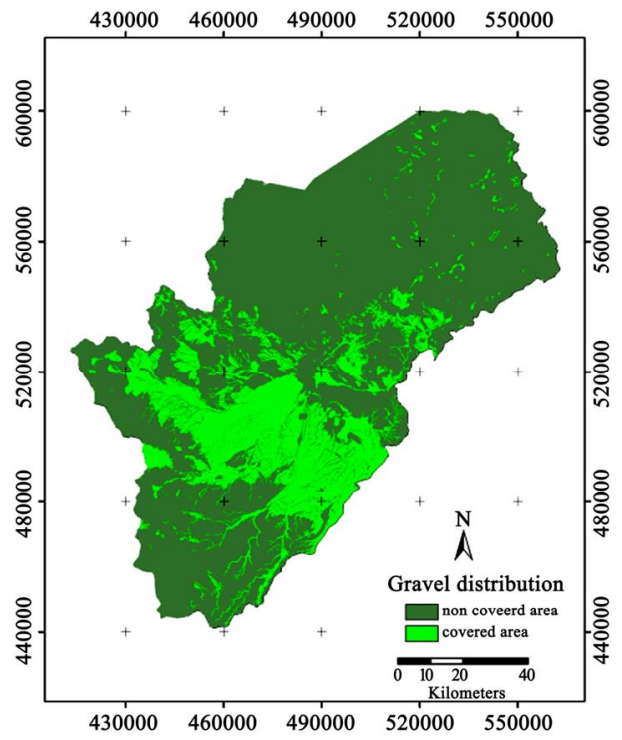

Figure 9. Gravel beds distribution in the study area.

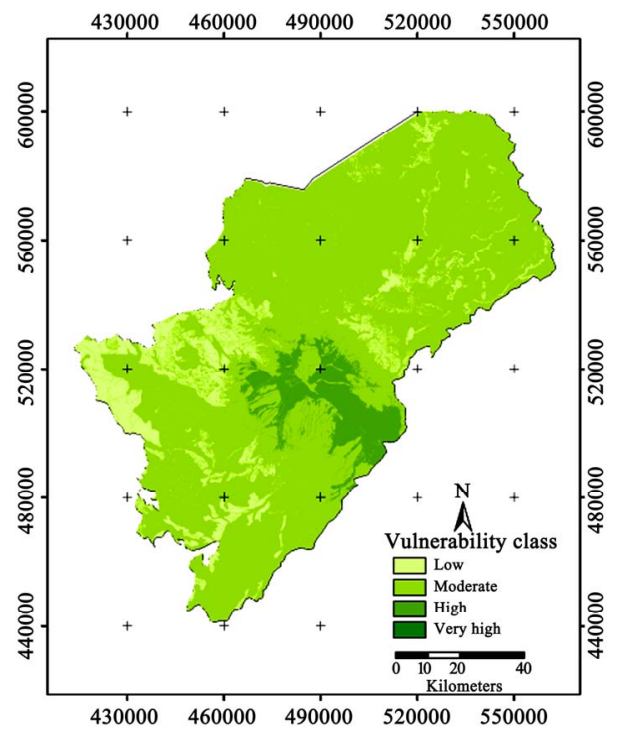

Figure 10. Final vulnerability map.

Table 11. Final rates of vulnerability factors, [10].

\begin{tabular}{cc}
\hline Value & Class \\
\hline$<50$ & Very low \\
$51-100$ & Low \\
$101-150$ & Moderate \\
$151-200$ & High \\
$>201$ & Extremely high \\
\hline
\end{tabular}

contain nitrate, rascal bacteria and eventually human medical residues.

Groundwater bodies vulnerable to agricultural and irrigation activities may contain biocides, fertilizers and 
other specific pollutants.

The same case can be said about groundwater exposed to industrial activities. This groundwater must contain residues of the specific industry if they are vulnerable to that industry

But, in urban areas, mainly $\mathrm{NO}_{3}$ concentrations, coli or E. coli lab tests results are used to determine the degree of water contamination in different locations of the aquifer. Accordingly, concentration maps must be drawn for such pollutants concentration in groundwater. Comparison of the vulnerability map and actual pollution map results indicate the correctness of the used methods and parameters

In this paper $\mathrm{NO}_{3}$ concentration map (MWI, 2010) was used to validate the groundwater vulnerability results. The distribution of $\mathrm{NO}_{3}$ concentration ranged from $0.2 \mathrm{mg} / \mathrm{l}$ up to $40.1 \mathrm{mg} / \mathrm{l}$ as shown in Figure 11.

It could be noticed that the wells with the higher $\mathrm{NO}_{3}$ concentrations are those in the agricultural and urban areas centers. This map coincides to a good degree with produced groundwater vulnerability map. This indicates at the correct method and correct parameters used in the evaluation.

\subsection{Protection Zones}

The concept of a 'zone of protection' for areas containing groundwater has been developed and adopted in a number of countries to help in landuse planning, with the aim of preventing groundwater resources degradation. The groundwater vulnerability mapping is a very helpful technique in locating the protection zones [20,21]).

Very low and low vulnerability class areas should be considered as protection zone 1 , where all activities such as agricultural, industrial and urban are convenient in this zone with low conditions of groundwater protection. Wastewater treatment plant and waste disposal sites are compatible to construct here with high conditions of groundwater protection.

Moderate vulnerability class areas should be considered as protection zone 2, where agricultural activities and urban areas without wastewater treatment plant or waste disposals are valid to construct. Suitable conditions of groundwater protection must be considered in this zone.

High and very high vulnerability classes areas considered as protection zone 3, where only very controlled urban activities with a very good sewage network and without any harmful residues. In addition, agricultural activities (with limited pesticides and insecticides) are possible.

So the Azraq basin area is divided into 3 protection zones (1, 2 and 3$)$ according to the vulnerability classes as shown in Figure 12.



Figure 11. $\mathrm{NO}_{3}$ concentration map from different well located in the basin.

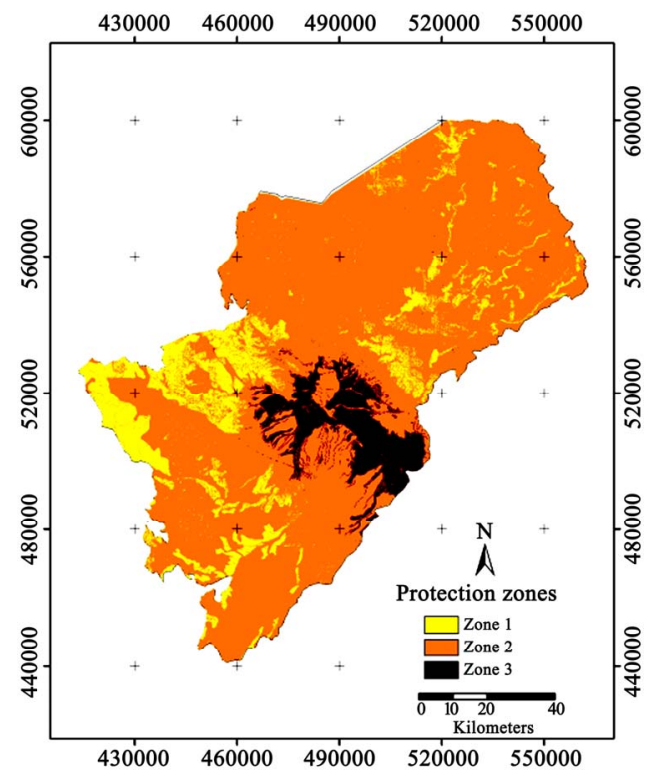

Figure 12. protection zones distribution in the Azraq basin area.

\section{Conclusions}

Azraq basin area devided into four vulnerability classes areas according to its environmental and froundwater setting, ranging from low, moderate, high and very high vulnerability classes.

Distribution of urban centers, agricultural and small scaled industrial activities in the Azraq basin area represent a pollution potential to the groundwater and those factors give higher vulnerability rates to the area that 
located in, environmentally setting of the groundwater in the area reflects very high and high vulnerability classes according to the combination of different factor such as depth to the groundwater and the recharge rates, other areas represents moderate vulnerability classes, and just small areas represents low vulnerability rate.

According to this map a well controlled landuse map and a detailed environmental impact assessment studies for the groundwater to any project must be done before establishing any project.

Validation map were drawn to the contaminants of the groundwater and the resulted map showed a high concentration of potential pollutants in the moderate and high vulnerability classes which validated the index.

A final protection zones map drawn to the area and such a map must used as a guide to help in protecting the groundwater and then preventing harmful contaminations.

\section{References}

[1] Water Authority of Jordan (WAJ) (2005): Internal files for groundwater basins in Jordan.

[2] Vrba, J. \& Zoporozec, A. [eds.] (1994): Guide book on Mapping Groundwater Vulnerability. - International Contributions to Hydrogeology (IAH), 16: 131 p.; Hannover.

[3] Merchant, J. M (1994). GIS-Based groundwater pollution hazard assessment: A critical review of the DRASTIC Model. Photograommetric Engineering \& Remote sensing, Vol. (60), No. (9), pp. 1117-1127.

[4] Engel et al., 1996. B.A. Engel, K.C.S. Navulur, B.S. Cooper and L. Hahn, Estimating groundwater vulnerability to non-point source pollution from nitrates and pesticides on a regional scale. In: (1996), pp. 521-526 (IAHS Publication No. 235).

[5] R.C. Knox, D.A. Sabatini and L.W. Canter, Subsurface transport and fate processes., Lewis Publishers, USA (1993).

[6] Murray, K., S., and Rogers, D, T (1999). Groundwater vulnerability, Brownfield Redevelopment and Land Use Planning. Journal of Environmental Planning and Management. Vol. (42), No. (6), pp. 801-810.

[7] IUCN, 2010, Azraq oasis restoration project, regional office for west asia ROWA, Jordan.
[8] Fortin, M., Thomson, K., P., B. and Edwards, G (1997). The role of error propagation for integrating multisource data within spatial models: the case of the DRASTIC groundwater vulnerability model, Earth Surface Remote Sensing Procedure SPIE conference, London, pp 358361.

[9] Fritch, T., G. et al. (2000). An aquifer vulnerability assessment of the paluxy aquifer, central Texas, USA, using GIS and a modified DRASTIC approach. Environmental Management, Vol. (25), No. (3), pp. 337-345.

[10] Jasem, H. (2009) Groundwater vulnerability assessment in wadi Kafrain catchment area and its surroundings_using GIS, ground truthing and lab analysis_. PhD thesis, University of Jordan, Jordan.

[11] Aller, L., Bennett, T., Lehr, J. H., Petty, R. J., Hackett, G. (1987). DRASTIC: A standardized system for evaluating ground water pollution potential using hydrogeologic settings. U.S. Environmental Protection Agency, EPA/600/ 2-87/036, 622pp.

[12] MWI - Ministry of Water and Irrigation (2010), open files.

[13] Esri, environmental system research institution, 2006. Arc view GIS 9.1, computer software to visualize explore query and analyze data spatially, USA.

[14] Piscopo, G (2001). Groundwater vulnerability map, explanatory notes, Castlereagh Catchment, NSW Department of Land and Water Conservation, Australia.

[15] NRA, 1993, Azraq basin geologic map.

[16] SUBAH, A. \& HOBLER, M. (2004): Groundwater Resources of Northern Jordan, Special Report No. 7: Hydrogeological Proposal for the Delineation of a Groundwater Protection Area for the Qunayyah Spring. - Unpubl. report, BGR archive no. 0126726, 30 p.; Amman.

[17] MOA - Ministry of Agriculture. (1993). National soil map and land use project. The soils of Jordan. Hunting Technical services Ltd. In association with Soil Survey and Land. Research Center. Vol. 3 Level 1.

[18] MOA - Ministry of Agriculture. (1993). National soil map and land use project. The soils of Jordan. Hunting Technical services Ltd. In association with Soil Survey and Land. Research Center. Vol. 2 Level 1.

[19] Adams B and Foster SSD, 1992. Land-surface zoning for groundwater protection. Journal of the Institution of Water and Environmental Management, 6: 312-320.

[20] US EPA 1993 Guidelines for delineation of wellhead protection areas EPA 440/5-93-001. 